\title{
SOME IMPROVEMENTS AND AMENDMENTS TO THE NOMENCLATURE OF MEADOWS AND ALPINE CARPETS FROM THE GREAT CAUCASUS
}

\author{
KONSTANTIN KOROTKOV
}

\begin{abstract}
Konstantin Korotkov, Institute of Ecology and Evolution, Russian Academy of Sciences, Lenin Avenue 33, 119071 Moscow,
\end{abstract} Russia; e-mail:quaken@mail.ru

New names of alpine carpet syntaxa (Korotkov 2006) were published invalidly [Art. 3o, International Code of Phytosociological Nomenclature (ICPN 3), Weber et al. 2000] because the word 'typus' was not used expressis verbis for the designation of the type of syntaxa names (Art. 5 of ICPN 3). Therefore these syntaxa names should be validated in the following form, corresponding to Art. 5, 3o, 9 and 10b of ICPN 3.

Carici pyrenaicae-Colpodietum pontici ass. nov. hoc loco

TYPUS: Table 2, relevé 3 (Korotkov 2006, pp. 286-287).

Geranio gymnocauli-Taraxacetum confusi ass. nov. hoc loco

TYPUS: Table 3, relevé 5 (Korotkov 2006, p. 289).

Carici atratae-Anthoxanthetum odorati ass. nov. hoc loco

TYPus: Table 4, relevé 2 (Korotkov 2006, pp. 291292).

\section{Colpodio variegati-Taraxacetum crepidiformis} ass. nov. hoc loco

Typus: Table 5, relevé 17 (Korotkov 2006, pp. 294 295).

Agrostio lazicae-Minuartietum imbricatae ass. nov. hoc loco

TYPUS: Table 6, relevé 5 (Korotkov 2006, pp. 297-298).
Colpodion variegati all. nov. hoc loco

TYPUS: Colpidio variegati-Taraxacetum crepidiformis

Three alpine meadow associations - Nardo strictae-Geranietum gymnocauli, Polygono vivipari-Kobresietum bellardi and the subassociation Potentilletum crantzii kobresietosum - were published (Korotkov \& Belonovskaya 2001a, b), also invalidly, because no types were explicitly mentioned (Art. 5 of ICPN 2, Barkman et al. 1986). Later an attempt to validate Nardo strictaeGeranietum gymnocauli and Potentilletum crantzii was made (Korotkov \& Belonovskaya 2002). This proved to be a failed effort, however, because the new edition of ICPN, requiring the use of the word 'typus' expressis verbis to indicate types, became res judicata just prior to publication. Unfortunately again the types were assigned to units with mistakes. The following validation conforms to ICPN rules.

Nardo strictae-Geranietum gymnocauli ass. nov. hoc loco

TYPUS: the following auct. relevé 183, 27.07.1994 by K. Korotkov.

Karatchay, Teberdinsky State Reserve, not far from the border with Abkhasia, above waterfalls, $2800 \mathrm{~m}$ a.s.1., on the $5^{\circ} \mathrm{SSW}$ slope to the Ptysh River, herb cover $75 \%$, moss cover 3\%, lichen cover 3\%. Species and abundance (BraunBlanquet cover scale): Geranium gymnocaulon DC. 3, Nardus stricta L. 2, Campanula tridentata 
Schreb. 1, Carum meifolium (Bieb.) Boiss. 1, Anthoxanthum odoratum L. 1, Veronica gentianoides Vahl 1, Colpodium variegatum (Boiss.) Griseb. 1, Festuca ovina L. 1, Sibbaldia procumbens L. 1, Cerastium purpurascens Adams in F. Weber \& D. Mohr 1, Carex umbrosa Host 1, C. atrata L. +, Anemone speciosa Adam ex Pritz. +, Gagea liotardi (Sternb.) Schult. \& Schult. +, Luzula multiflora (Ehrh.) Lej. +, L. spicata (L.) DC. +, Ranunculus oreophilus M. Bieb. + , Corydalis alpestris C. A. Mey. +, Minuartia imbricata (M. Bieb.) Woronow +, Chamaesciadium acaule (M. Bieb.) Boiss. +, Antennaria dioica (L.) Gaertn. +, Potentilla cranzii (Crantz) Beck ex Fritsch + , Sedum tenellum M. Bieb. +, Taraxacum crepidiforme DC. +, Hedysarum hedysaroides (L.) Schinz \& Thell. +, Campanula collina Sims + , Cirsium simplex C. A. Mey. +, Abietinella abietina (Hedw.) M. Fleisch. +, Desmatodon latifolius (Hedw.) Brid. +, Pohlia cruda (Hedwig) Lindberg + , Rhytidium rugosum (Hedwig) Kindberg +, Cetraria islandica (L.) Ach. + .

Nardo strictae-Geranietum gymnocauli cerastietosum purpurascentis ass. nov. hoc loco

TYPUS: the same as for association.

Nardo strictae-Geranietum gymnocauli festucetosum variae subass. nov. hoc loco

TYPus: Table 4, auct. relevé 53 (Korotkov \& Belonovskaya 2001a, pp. 23-25), and the same as in Table 1, field relevé 53 (Korotkov \& Belonovskaya 2001b, pp. 328-331).

Polygono vivipari-Kobresietum bellardi ass. nov. hoc loco

TYPus: Table 4, auct. relevé 152 (Korotkov \& Belonovskaya 2001, pp. 26-28), and the same as in Table 1, field relevé 152 (Korotkov \& Belonovskaya 2001b, pp. 328-331).

Potentilletum crantzii ass. nov. hoc loco, and Potentilletum crantzii vaccinietosum myrtilli subass. nov. hoc loco

TYPUS: Table 5, auct. relevé 21 (Korotkov \& Belonovskaya 2001, pp. 29-31).
Pohlia nutans (Hedw.) Lindb. + was omitted in the above mentioned publication.

\section{Potentilletum crantzii kobresietosum simpliciu-} sculae subass. nov. hoc loco

TYPUS: Table 5, auct. relevé 8 (Korotkov \& Belonovskaya 2001, pp. 29-31), and the same as in Table 1, field relevé 8 (Korotkov \& Belonovskaya 2001b, pp. 334-337).

Anemono speciosae-Campanuletum tridentatae eritrichietosum nanae Korotkov \& Belonovskaya (Korotkov \& Belonovskaya 2001b) was published with a wrong ending in the species epithet and should be corrected to Anemono speciosae-Campanuletum tridentatae eritrichietosum nani Korotkov \& Belonovskaya according to Art. $40 \mathrm{~b}$ and 48 of ICPN 3.

Four subalpine meadow associations from the northern slope of Skalisty (Rocky) Ridge, Inulo orientalis-Pedicularietum condensatae, Cephalario giganteae-Tanacetetum coccinei, Carici caespitosae-Ligularietum subsagittatae, and Cirsio pugnacis-Trifolietum ambigui - were published as provisional (Korotkov \& Tzepkova 1991) and need validation according to Art. $3 \mathrm{~b}$ of ICPN 2 (Barkman et al. 1986). The following validation conforms to ICPN 3 rules.

Inulo orientalis-Pedicularietum condensatae ass. nov. hoc loco

TyPus: Table 3, relevé 22 (Korotkov \& Tzepkova 1991, pp. 75-82).

Cephalario giganteae-Tanacetetum coccinei ass. nov. hoc loco

Typus: Table 5, relevé 6 (Korotkov \& Tzepkova 1991, pp. 87-89).

Carici caespitosae-Ligularietum subsagittatae ass. nov. hoc loco

TYPus: Table 4, relevé 47 (Korotkov \& Tzepkova 1991, pp. 84-85).

Cirsio pugnacis-Trifolietum ambigui ass. nov. hoc loco

TyPuS: Table 7, auct. relevé 34 (Korotkov \& Tzepkova 1991, pp. 93-95). 
Astrantion maximae all. nov. hoc loco

TYPUS: Inulo orientalis-Pedicularietum condensatae.

To avoid later rejection of syntaxa names according to Art. 3f of ICPN 3 or correction according to Art. 43 of ICPN 3, here I list some potentially confusing plant species names used in this publication, with their substitutes:

Carex pyrenaica Wahl. instead of Carex micropodioides Krecz.

Colpodium ponticum (Bal.) Woronow instead of Hyalopoa pontica (Bal.) Tzvel.

Carex atrata L. instead of Carex medwedewii Lesk.

Anthoxanthum odoratum L. instead of Anthoxanthum alpinum A. Löve \& D. Löve

Colpodium variegatum (Boiss.) Griseb. instead of Catabrosella variegata (Boiss.) Tzvel.

Taraxacum crepidiforme DC. instead of Taraxacum stevenii sensu Hand.-Mazz. (1907) non (Sprengel) DC. (1838) Schur

Festuca ovina L. instead of Festuca supina

Carex umbrosa Host instead of Carex huetiana Boiss.

Gagea liotardi (Sternb.) Schult. \& Schult. instead of Gagea fistulosa (Ram. ex Lam. \& DC.) Ker.-Gawl, G. anisanthos C. Koch

Antennaria dioica (L.) Gaertn. instead of Antennaria caucasica Boris.

Hedysarum hedysaroides (L.) Schinz \& Thell. instead of Hedysarum caucasicum M. Bieb.

Festuca varia Haenke instead of Festuca woronowii Hack.

Kobresia bellardii (All.) Degland non Hartm. instead of Kobresia capillifolia (Decne) Clarke, $K$. cappiliformis Ivanova

Kobresia simpliciuscula (Wahl.) Mackenzie instead of Kobresia persica Kuk. \& Bornm., K. humilis (C. A. Mey. ex Trautv.) Serg.
Tanacetum coccineum (Willd.) Grierson instead of Pyrethrum roseum (Adams) M. Bieb.

Luzula multiflora (Ehrh.) Lej. instead of Luzula pseudosudetica (Krecz.) Krecz.

Sibbaldia procumbens L. instead of Sibbaldia parviflora Willd., S. semiglabra C. A. Mey.

Eritrichium nanum (All.) Schrad. ex Gaud. instead of Eritrichium caucasicum (Alb.) Grossh.

ACKNOWLEDGEMENTS. I am grateful to Jean-Paul Theurillat for drawing my attention to some of the invalidly published Caucasian syntaxa and for very carefully reviewing the paper.

\section{REFERENCES}

BARKMan J. J., Moravec J. \& Rauschert S. 1986. The Code of the Phytosociological Nomenclature. $2^{\text {nd }}$ edition. Vegetatio 67(3): 145-195.

KorotKov K. 2006. Snowbed communities and their relatives in the high mountains of the Greater Caucasus. In: J. HoleKsA, Z. MiReK \& J. J. WóJCiCKI (eds), Krystyna Falińska and Janusz B. Faliński Festschrift. Polish Bot. Stud. 22: 283-309.

Korotkov K. \& Belonovskaya E. 2001a. The Great Caucasus Alpine Belt Syntaxonomy. I. Alpine Meadows with Restricted Distribution, Vegetation of Russia, St. Petersburg 1: 17-35.

KorotKov K. \& Belonovskaya E. 2001b. Syntaxonomical Survey of Alpine Meadows in the Great Caucasus. Fragm. Florist. Geobot. 45(1-2): 323-343.

KorotKov K. \& BelonovsKayA E. 2002. Nomenclatural adjustments in the Juncetea trifidi syntaxa from the Great Caucasus. Polish Bot. J. 47(1): 67-68

KorotKov K. O. \& TzePKova N. L. 1991. Syntaxonomy of the grassland communities of Aursentkh Region (Central Caucasus). In: Vysokogornye ekosistemy pod vozdeistviem cheloveka. Trudy Vysokogornogo Geofizicheskogo Instituta 84: 52-109 (in Russian).

Weber H. E., MoraVec J. \& Theurillat J.-P. 2000. International Code of Phytosociological Nomenclature. $3^{\text {rd }}$ edition. Journal of Vegetation Science 11(5): 739-768. 